\title{
An Empirical Relationship Between Human Capital, Institutional Quality, and Economic Growth in Pakistan
}

\author{
Abdul Farooq ${ }^{1}$, Sarah Arshi $^{2}$, Nyla Sattar ${ }^{3}$ and Amber Khalil ${ }^{4}$
}

\begin{abstract}
Pakistan is a developing economy where different policies have been adopted to increase economic growth, but the targeted growth rates have remained an elusive dream. Low quality of institutions and less attention towards the development of human capital are two major reasons for this failure. This study explores the association of institutional quality and human capital on economic growth in Pakistan from the time period between years 1984 to 2018. For the estimation of our model, Auto-Regressive Distributed Lag (ARDL) model has been used. The variance decomposition analysis is also used to check the shocks, direction, and magnitude of the shocks within the selected variables. Impulse response function confirms that the magnitude and direction of the shocks are positive. The outcome of this research suggests that accumulation in human capital increases productivity, and institutional quality helps to sustain economic growth. Therefore, policy makers should design such policies, which are helpful for the development of human capital. It is also recommended that law and order situation be improved so that the confidence of people and trust of investors is restored that eventually will drive economic growth in Pakistan.
\end{abstract}

Keywords: Economic growth, Human capital, Institutional quality, ARDL.

JEL Classification: C15, D1, D63, E2, H2

\section{Introduction}

Human capital has a crucial role not only in the production process but also in all sectors of the economy. Due to effective rule of law, labor performs more efficiently in that specific sector and enhances economic growth.

Substantial and sustained economic growth is the primary goal of all economies. The nature of economic growth depends on both economic and noneconomic factors (Nawaz, 2015). Enhancing and maintaining economic growth are

\footnotetext{
${ }^{1}$ Assistant Professor, Department of Economics, COMSATS University Islamabad, Lahore Campus.

${ }^{2}$ Former student, Department of Economics, National College of Business Administration and Economics, Lahore.

${ }^{3}$ Former student, Department of Economics, National College of Business Administration and Economics, Lahore.

${ }^{4}$ Lecturer, Department of Management Sciences, Islamia University Bahawalpur, Bahawalnagar Campus.

The paper is based upon the M. Phil thesis of the second author.

Corresponding author's Email: afarooq@cuilahore.edu.pk
} 
two different things. Whereas some reforms are needed to start the process of economic growth, continuous institutional reforms can maintain productive interest, as well as economic growth (Rodrik, 2003). Countries that protect the institutional quality and focus on macroeconomic stabilization will be able to invest more in both physical and human capital to achieve a higher level of income and economic growth (Qasim et al., 2016).

Developing economies have more capacity to catch up with the world but they are not observed to be effectively catching up; the reason for this is the poor quality of institutions (Knack and Keefer, 1997; Rodrik, 1999, 2003). Institutional argument is considered as the key role for the joint evolution of political and economic development which propels economic growth (Acemoglu et al., 2005). Institutions affect economic growth by shaping political, economic, and social interconnections in a society (North, 1990 \& 1991). The effect of institutional quality differs transversely when using a sub-sample of different economies (Eicher and Leukert, 2009). For example, the cultural and geographical characteristics of Pakistan and India are almost similar but in reality, the performance of democratic institutions is different from each other (Nawaz, 2015). On the other side, developed countries, for example, Hong Kong, Germany, Taiwan and the United Kingdom have high economic growth despite variances in the characteristics of institutional establishment in these countries (Valerian and Peluso, 2011). The quality of institutions is also plays an important role in enhancing the growth rate of an economy. As Barro $(1990,1991)$ point out that institutional quality helps to maintain growth rate in the long-run. Institutional rulers, in progress of an economy, operate largely through its major effect on human capital through efficiency of government provision, transfer to increase the learning outcome and structuring human capital (Adam-Kane and Lim, 2016). Improvement in institutional quality is linked with systematic development of human capital, which further increases growth rate in different sectors of the economy (Zhou, 2016, 2018).

Human capital is an important asset of every nation. The development of human capital is considered an essential condition for economic growth (Schultz, 1993; Qaiser and Winte, 2001; Abbas, 2001). Effective and qualitative human capital enhances the productivity and efficiency of the production process (Harbinson and Myer, 1964; Todaro, 2002). Human capital is considered as a prime source of growth ranking higher superior compared to institutional quality according to Glaeser et al. (2004). This is one of the reasons that South Asia has to stress on higher level of education to improve human capital (Riboundand Tan, 2009). 
Today, Pakistan is half of the country it was in 1947 as $55 \%$ of the population lived in East Pakistan. The economy of Pakistan is much spectacular as compared to the growth of its early years. Pakistan would necessarily have grown from whatever existed in endowment (Khan, 2005). Since 1947, Pakistan's economy has been unable to maintain economic growth. The governments did not examine the essential fundamentals of human capital formation and development in infrastructure for the progress in economic growth. Pakistan scored 53.10 according to the human capital index 2016 and ranked $118^{\text {th }}$ among 130 countries (Human Capital Report, 2016). What is distressing is that this rank was an improvement from the previous years. On the other hand, with regards to economic growth, it has fluctuated over the years and even became negative a few times in Pakistan. Although the performance of institutional quality has improved over the years, this improvement has not been much impressive. Law and order index ranges from 0 to 6 ( 0 Poor; $6 \mathrm{Good}$ ), and the index value observed in the past years show that the law and order condition in Pakistan is not adequate. Trend shows a slight improvement in law-and-order condition from 1984-1997. In the year 1998, its value decreased from 3.92 points to 3.00 points and remained the same till 2009. After that, the law and order condition improved and reached 3.50 points in 2012, and during the year 2016, its value again dropped to 3.00 points for Pakistan (International Country Risk Gide, 2016).

Institutional quality and human capital together can substantially boost economic growth in a country. Human capital in the case of Pakistan, has not received much attention from the policy makers while institutional quality is also lagging, which causes hurdles in the progress of the economy. Pakistan is a labor augmented country but still lies at the bottom among the lowest fifteen countries. The reason behind this is the poor performance on educational outcomes through all age groups (Human Capital Report, 2016). There is approximately 61.04 million working age population out of an estimated total population of 195.4 million. This shows that the ratio of dependent population is much higher in Pakistan (Labour Force Survey, 2014-15; Bhattacharjee, 2016; Pakistan Economic Survey, 2015-16). Pakistan ranked 134 out of 157 countries in the human capital index (HCI), during the year 2018. The condition of Pakistan's HCI is very critical by comparing with other Asian countries; Bangladesh ranked as 106, India 115, Afghanistan 133 (Nasir, 2018).

In this backdrop, the basic purpose of this research is to determine the impact of human capital and institutional quality on the growth of Pakistan's economy. We hypothesize that "there is a significant positive impact of human capital on economic growth of Pakistan" and "better quality of institutions enhance 
economic growth in Pakistan". This study also aims to trace the reasons for unstable economic growth in the country.

\section{Literature Review}

For effective human capital, spending on education has a strong impact, which later assists in enhancing economic growth. Effective labor played a vital role in the progress of economic growth both in the short and long run (Afridi, 2016). The specific group of people who have enough knowledge (human capital) had better ideas of substitution for the usage in manufacturing and commercial trade, which further enhances productivity level and boosts economic growth (Lucas, 1988; Sokoloff and Khan, 1989; Romer, 1990; Knack and Keefer, 1997; Barro, 1998; Stewart et al., 1998; Abbas, 2000; Abbas, 2001; Castelló and Doménech, 2002; Khan, 2005; Abbas and Foreman-Peck, 2007; Asghar et al., 2012; Angeles, 2010; Ali et al., 2012; Asghar et al., 2012; Mehrara and Musai, 2013; Yilmazer and Cinar, 2015; Afridi, 2016; Zhuo, 2018). Economic growth is affected by strong institutional quality, which plays a mediating effect on human capital accumulation (Acemoglu et al., 2004; Gleaser et al, 2004; Khan, 2005; Angeles, 2010; Dias and Tebaldi, 2012; Acemoglu et al., 2014; Adams-Kane and Lim, 2016). Better institutional quality is necessary for sustainable economic growth (Acemoglu et al., 2004; Gleasure et al., 2004; Nawz, 2005; Levchenko, 2007; Angeles, 2010; Slesman et al., 2015; Bhattacharjee, 2016). There is a need to work on labor skill management and remove trade barriers to enhance economic growth rate, specifically in the case of underdeveloped economies (Tariq et al., 2016).

Although researchers have examined the relationship between human capital and institutional quality on economic growth separately, there is a need to investigate the role of human capital on economic growth in the presence of institutional quality. Some literature also sheds light on the significance of institutions for a country's economic prosperity as low institutional quality reduces the confidence for investment and also deters the development of human capital. Despite the attempt by these studies, no clear evidence has linked human capital to economic growth along with institutional quality in the case of Pakistan. The impact of human capital on economic growth in the presence of institutional quality is missing. Based on the reviewed literature, we also observe that there are mixed findings with a number of studies proposing a positive relationship of human capital and institutional quality on economic growth, while others arguing for a negative relationship (See for example, Adam-Kane and Lim, 2016; Tariq et al., 2016; Nawaz, 2015, Baum and Lake, 2003). Another point to note is that cross-country 
studies on this topic do not effectively capture significant and specific characteristics of countries, which are important factors to consider in economic growth models. Cross-country studies, especially with reference to production inputs, also sometimes suffer from measurement problems (Tallman and Wang, 1994; Tamura, 1991; Becker et al., 1990). Therefore our main motivation in this paper stems from the dearth of studies that explore the link between human capital and institutional quality on economic growth. Specifically, we aim to conduct a country analysis of Pakistan, which does not suffer from cross-country biases as discussed above.

\section{Data and Methodology}

Improvement in human capital and strong institutional setup are important factors for economic growth (Afridi, 2016; Tariq et al., 2016). This research work has augmented the Mankiw-Romer-Weil (1992) model by adding new variables such as, institutional quality, inflation, and trade openness, as these variables are considered important in measuring the growth of the economy (Ali et al., 2016; Tariq et al., 2016; Nawaz, 2015; Sarel, 1996; Knack and Keefer, 1995).

The functional form of the model for this study is as follows;

$$
\mathrm{EG}=f(\mathrm{GCF}, \mathrm{HCI}, \mathrm{INS}, \mathrm{INF}, \mathrm{TO})
$$

The econometric form of the model is:

$$
E G_{t}=\alpha_{0}+\alpha_{1} G C F_{t}+\alpha_{2} H C I_{t}+\alpha_{2} I N S_{t}+\alpha_{3} C P I_{t}+\alpha_{5} T O_{t}+\varepsilon_{t}
$$

Where $\alpha_{0}$ is the constant; $\alpha_{1}, \alpha_{2}, \alpha_{3}, \alpha_{4}, \alpha_{5}$ are the coefficients; $t$ is showing the time period. $\mathrm{EG}_{\mathrm{t}}$, represents real GDP per capita at time $\mathrm{t}, \mathrm{GCF}_{\mathrm{t}}$ is gross capital formation in billion rupees at time $t$, INS is the institutional quality, proxied by law and order, CPI is inflation rate measured by the consumer price index, and TO is trade openness measured as the ratio of import and export as a ratio to GDP. HCI is the human capital index. Meanwhile, $\epsilon_{\mathrm{t}}$ is the disturbance term. Variables such as human capital; gross capital formation; institutional quality; rate of inflation and trade openness have been frequently used in growth researches (See for example, Ali et al., 2016; Afridi, 2016; Tariq et al., 2016; Nawaz, 2015; Sarel, 1996; Knack and Keefer, 1995).

For the estimation of our model, we have used a time-series dataset for Pakistan over the time period 1984-2018. Time series analysis was also preferred in this case because of the variation in measurement of institutional quality of each country as each have distinctive institutional policies (Nawaz, 2015; Valerian and Peluso, 2011; Ahmed, 2006). GDP per capita is measured at constant local currency 
unit. Gross capital formation is used to measure physical capital. Human capital is measured by using the human capital index based on one-year schooling and return to education, from the Penn World Tables. For the variable of institutional quality, we have used the proxy of law and order. Better law and order situation translates into better institutions. For inflation, we have used the consumer price index (CPI).

The impact of institutional quality and human capital on economic growth is measured using time series analysis and ARDL estimation was considered as an efficient analytical method for analysis since it allows us to include data for Pakistan at time period t. ARDL bound testing for cointegration was used to check the long-run relationship of the selected model.

\section{Results and Discussion}

Logarithm form of the selected model is used for econometric analysis and unit root tests are applied to check the stationarity level of each variable. Augmented dickey Fuller (ADF) test and Phillips Perron (PP) unit root tests have been applied to examine the unit root estimations.

Table 1: Unit Root Test

\begin{tabular}{lcccc}
\hline Variable & ADF Test & Stationary & \multicolumn{1}{c}{ PP Test } & Stationary \\
\hline \multirow{2}{*}{ LNEG } & -3.488715 & $\mathrm{I}(1)$ & -3.49526 & $\mathrm{I}(1)$ \\
& $0.0147^{* *}$ & & $0.0145^{* *}$ & \\
LNGCF & -3.83017 & $\mathrm{I}(0)$ & -4.73787 & $\mathrm{I}(1)$ \\
& $0.0282^{* *}$ & & $0.0006^{*}$ & \\
LNINST & -3.224861 & $\mathrm{I}(0)$ & -4.35028 & $\mathrm{I}(1)$ \\
& $0.0982^{* *}$ & & $0.0016^{*}$ & \\
LNHC & -1.380212 & $\mathrm{I}(1)$ & -1.81078 & $\mathrm{I}(1)$ \\
& $0.0525^{* *}$ & & $0.0676^{* *}$ & \\
LNCPI & -4.99989 & $\mathrm{I}(0)$ & -2.45304 & $\mathrm{I}(1)$ \\
& $0.0018^{*}$ & & $0.0348^{* *}$ & \\
LNTRADE & -6.655808 & $\mathrm{I}(1)$ & -6.65489 & $\mathrm{I}(1)$ \\
& $0.0000^{*}$ & & $0.0000^{*}$ & \\
\hline
\end{tabular}

Note: $* \& * *$ are $1 \%$ and $5 \%$ level of significance respectively.

The results of ADF test confirmed that economic growth, human capital and trade openness are stationary at first difference while gross capital formation, institutional quality, and inflation are stationary in the level form. The result of the PP unit root test predicts that economic growth, gross capital formation, institutional quality, human capital, inflation and trade openness, all selected variables are stationary at first difference. The results of the unit root analysis 
suggest applying ARDL bound testing for cointegration to check whether a longrun relation of the selected model exists.

The results of the unit root test suggested that we apply the ARDL bound testing for cointegration to test for the presence of a long-term relationship in the selected model. The results of the bound test are presented in table 2. The results confirm that a long-run relationship exists in the selected model as the upper bound is less than the test statistic (F-value).

Table 2: ARDL Bounds Testing

\begin{tabular}{lllll}
\hline \multicolumn{1}{c}{ Estimated Model } & Optimal Lag Length & F-Statistics & $\mathrm{I}(0)$ & $\mathrm{I}(1)$ \\
\hline $\begin{array}{l}\text { FlnEG (lnEG/InGCF, } \\
\text { lnTRADE) }\end{array}$ & $1,3,2,3,3,1$ & $5.171287^{*}$ & 3.41 & 4.68 \\
\hline
\end{tabular}

Note: * denotes $1 \%$ level of significance.

Various stability tests confirmed that there is no serial correlation in the data and heteroskedasticity test also confirmed that the variance of the model is constant over time with zero mean.

Table 3 shows the long and short-term analyses for the selected model. Human capital and institutional quality both have a significant impact on the economic growth of Pakistan in congruence with literature (Tariq et al., 2016; Dias and Tebadli, 2012; Ali et al., 2012; Khan, 2005). Strong institutional quality is the result of the implementation of law and order. It attracts investors for a secure investment that promotes businesses and boosts economic growth. Institutional quality positively impacts economic growth of Pakistan and it has a significant relationship in both the short and long run. Specifically, a $1 \%$ increase in institutional quality causes a $0.003 \%$ increase in economic growth in the short run and a $0.013 \%$ increase in the long run.

These results are in contrast with the findings of Muarik (2005) and Faria and Carnerauski (2001) and in favor of the results of Bhattacharjee, 2016; Vijesandiran and Vinayathasan, 2015; Valeriani and Peluso, 2011; Fischer (1979); Sidrauski (1967) and Barro, 1990.

As Todaro (2002) pointed out that it is not easy to advance all other means of production in the absence of satisfactory and qualitative human capital, therefore, effective attention towards all factors of production, especially in human capital, will increase productivity, which accelerates economic growth. According to our estimation results, human capital has a positive and significant impact on the economic growth of Pakistan and these results are in favor of the studies conducted by Afridi, 2016; Nawaz, 2015; Mehrara and Musai, 2013; Lake, 2003; Stewart et 
al., 1998 and Abbas, 2000 while, inconsistent with the findings of Afridi (2016) in the short run estimation period. The results of the error correction model (ECM) confirmed that $53 \%$ is the speed of adjustment from the short run to the long run in one year.

Table 3: Short Run Analysis

\begin{tabular}{|c|c|c|c|c|}
\hline Variable & Coefficient & Std. Error & t-Statistic & Prob. \\
\hline $\mathrm{D}(\mathrm{LNGCF})$ & 0.134121 & 0.057934 & 2.315074 & $0.0376^{* *}$ \\
\hline D(LNINST) & 0.003467 & 0.003082 & 1.124921 & 0.281 \\
\hline $\mathrm{D}(\mathrm{LNHCI})$ & 0.69777 & 0.141662 & 4.925606 & $0.0003^{*}$ \\
\hline $\mathrm{D}(\mathrm{LNCPI})$ & -0.243686 & 0.104043 & -2.342172 & $0.0357 * *$ \\
\hline D(LNTRADE) & -0.0033 & 0.049145 & -0.067158 & 0.9475 \\
\hline CointEq(-1) & -0.530574 & 0.232566 & -2.281385 & $0.04 * *$ \\
\hline \multicolumn{5}{|c|}{ Long Run Analysis } \\
\hline LNGCF & 0.244308 & 0.24339 & 1.003775 & 0.3338 \\
\hline LNINST & 0.01354 & 0.005754 & 2.3532 & $0.035^{* *}$ \\
\hline LNHCI & 0.153367 & 0.069874 & 2.194896 & $0.0469 * *$ \\
\hline LNCPI & -0.335989 & 0.097089 & -3.460623 & $0.0042 *$ \\
\hline LNTRADE & 0.460245 & 0.254124 & 1.811105 & $0.0933 * * *$ \\
\hline $\mathrm{C}$ & -1.987982 & 0.21359 & -0.485688 & $0.0273 * *$ \\
\hline $\mathrm{R}^{2}$ & \multicolumn{4}{|l|}{0.87008} \\
\hline $\operatorname{Adj} \mathrm{R}^{2}$ & \multicolumn{4}{|l|}{0.69019} \\
\hline D.W. & \multicolumn{4}{|l|}{2.373539} \\
\hline F-Statistics & \multicolumn{4}{|c|}{$4.836747(0.002984)$} \\
\hline
\end{tabular}

Note: $* * *, * * *$ are $1 \%, 5 \% \& 10 \%$ significant levels respectively.

Figures 1 and 2 show the stability of data by making use of the cumulative sum control chart (CUSUM) and the cumulative sum control squared chart (CUSUMsq), which confirm that data is normally distributed as the cumulative sum of the recursive residuals, represented by the blue line, is between the lower and upper bounds, both in CUSUM and CUSUMsq. 
Figure 1: Cumulative Sum Control Chart

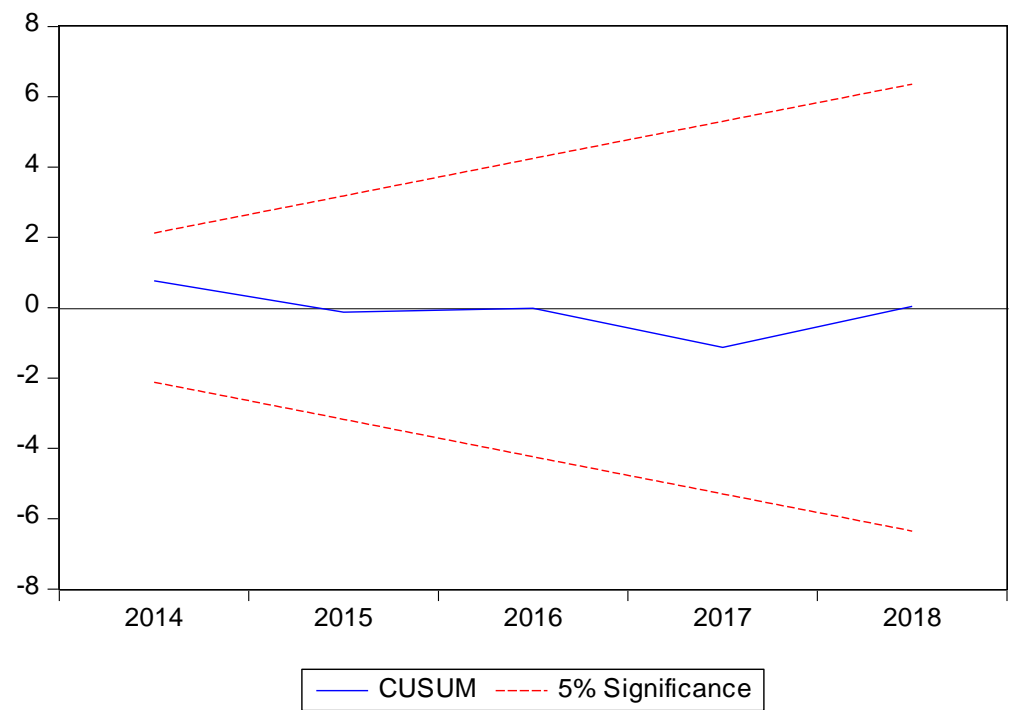

Figure 2: Cumulative Sum Control Squared Chart

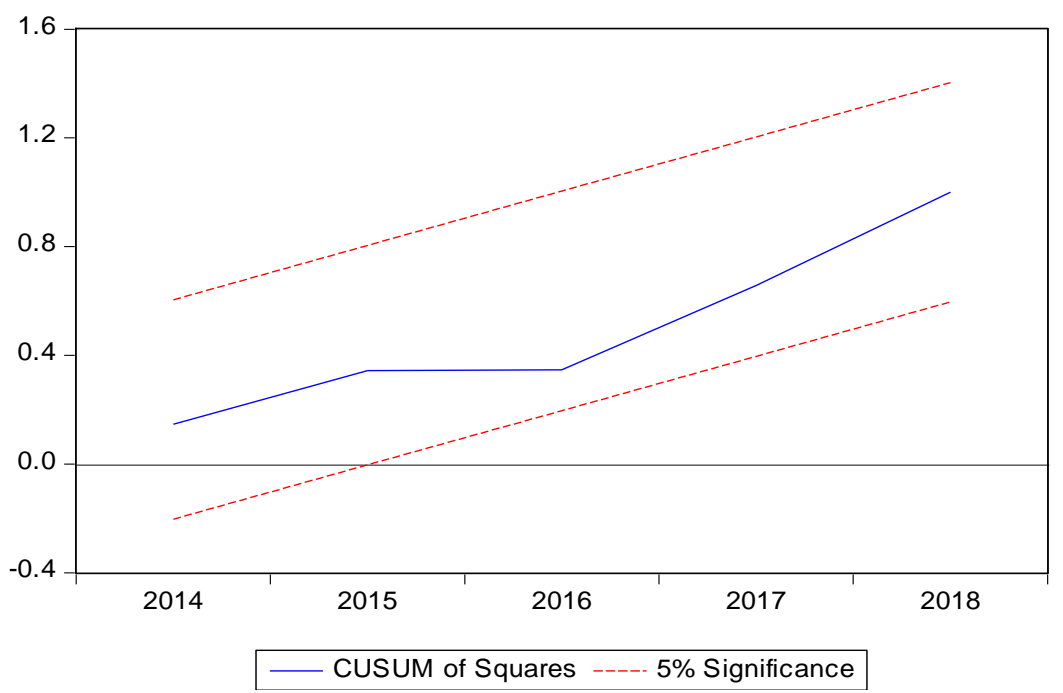

Christopher A. Sims developed the variance decomposition approach in time series analysis (Sim, 1992). This method introduces shocks and then details their effect on other variables and their magnitude over time. Variance decomposition analysis finds the impact of innovative shocks on the adjustment path of the variables under investigation. To see the results of variance decomposition analysis, see appendix 2 . The impulse response function, presented 
in figure 3 shows the direction of innovative shock and its magnitude. This illustration shows the impulse response function of economic growth to the human capital index. The contribution of economic growth to human capital is increasing; as shown in figure 3 . It shows that the direction of the shock is positive and increasing, from horizon 1 till the $4^{\text {th }}$ horizon. After the $4^{\text {th }}$ horizon, its direction becomes negative but the magnitude of the shock is still positive, till the $6^{\text {th }}$ horizon. From the $8^{\text {th }}$ horizon onward, both the magnitude and direction of the shock start to increase and become positive. This proves that the direction of the shock of economic growth to human capital is overall positive.

Figure 3: Response of LNEG to LNHCI

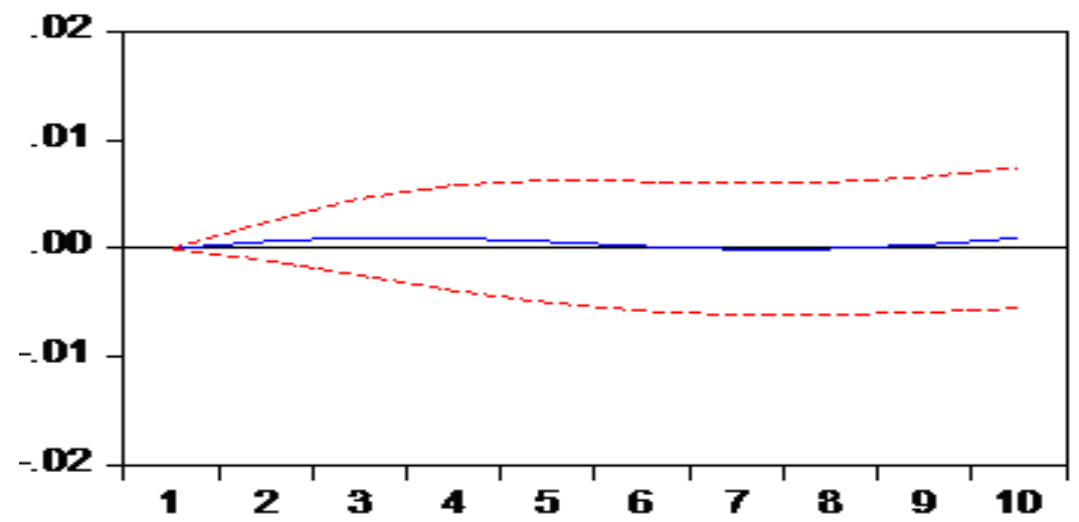

Figure 4: Response to LNHCI to LNEG

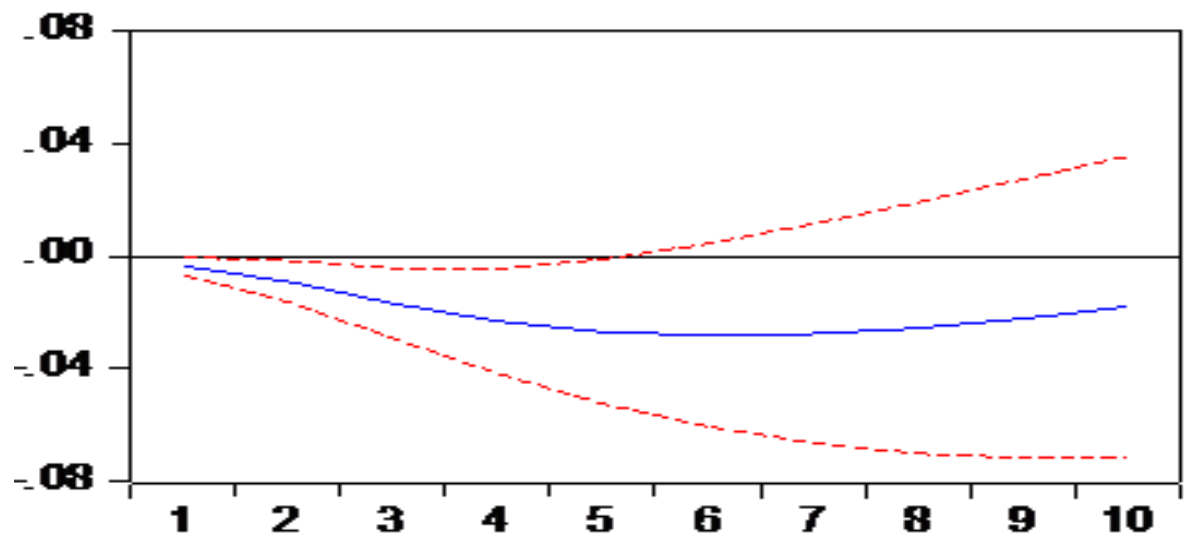

Figure 4 shows the impulse response function of the human capital index to economic growth. The contribution of human capital index to economic growth is initially decreasing and then has an increasing trend. The direction of the shock is 
decreasing from the human capital index to economic growth and its magnitude is negative, till the $6^{\text {th }}$ horizon. After the $6^{\text {th }}$ horizon, the direction of shock increases and the magnitude remains negative from human capital to economic growth. The speed of increase in shock is less as compared to the speed of decrease in shocks from human capital to economic growth. This proves that the direction of the shock of human capital to economic growth was decreasing in the beginning, while as time passed its shock drifted towards the positive horizon.

Figure 5: Response to LNEG to LNINST

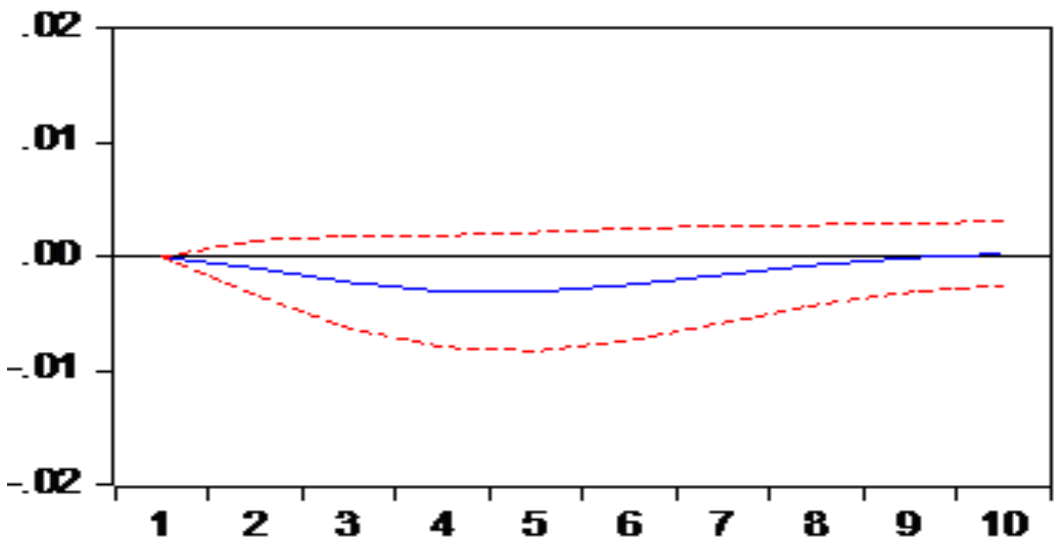

Figure 5 shows the impulse response function of economic growth to the institutional quality of Pakistan. The contribution of economic growth to institutional quality is at the beginning decreasing and then has an increasing trend. The direction of the shock is decreasing from economic growth to institutional quality and the magnitude is negative till the $4^{\text {th }}$ horizon. After the $5^{\text {th }}$ horizon, the direction of shock becomes increasing and the magnitude remains negative. The magnitude of shock is positive and increases right after the $8^{\text {th }}$ horizon. This proves that the direction of shock of economic growth to institutional quality was initially decreasing, while as time passed its shock moved towards the positive horizon to become positive.

Figure 6 shows the impulse response function of institutional quality to the economic growth of Pakistan. In the first horizon, the direction of shock is increasing, and its magnitude is negative. After that it becomes positive and in the $3^{\text {rd }}$ horizon its direction is decreasing and magnitude again becomes negative. In the $4^{\text {th }}$ horizon of impulse response function, the direction of shock, from institutional quality to economic growth is increasing as it reaches the $9^{\text {th }}$ horizon 
and then again has a decreasing trend but with slow speed. The magnitude of the shock is negative in the $4^{\text {th }}$ and $5^{\text {th }}$ horizon. However, from the mid of the $5^{\text {th }}$ horizon onwards, its magnitude turns positive. Overall, the impulse response function from institutional quality to economic growth is positive. The rest of the shocks for other variables studies in this research are shown in appendix 1.

Figure 6: Response of LNINST to LNEG

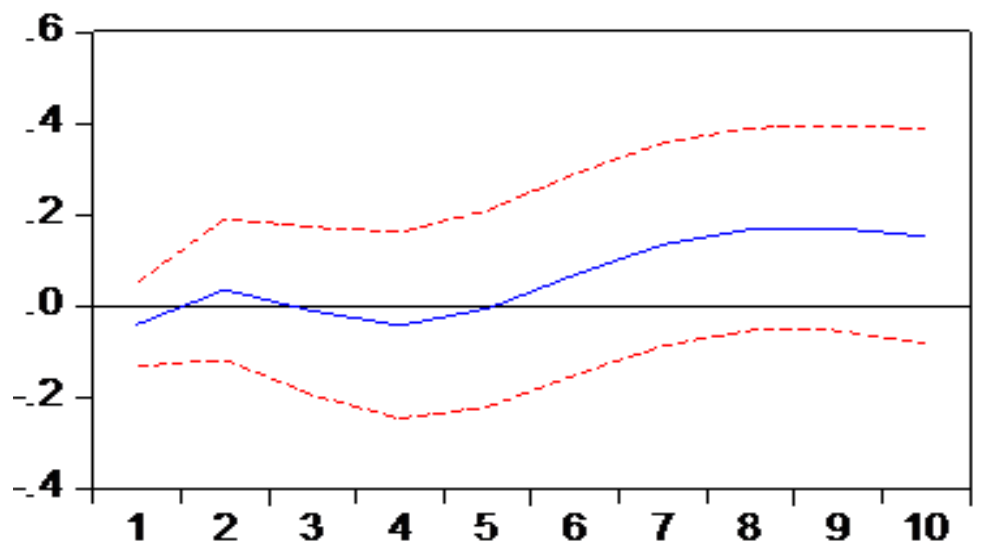

\section{Conclusion}

The present study uses time series analysis for the period from year 1984 to 2018 to investigate the impact of human capital and institutional quality on economic growth of Pakistan. By testing the variables for stationarity using unit root tests, we applied the ARDL technique for estimation of the model. The stability of our data was checked through the CUSUM and CUSUM squared approaches. Variance decomposition analysis, an innovative accounting approach, is also used to check the direction and magnitude of shocks in variables with the same variable and with the other variables to determine the overall direction of relationship that exists.

Results demonstrate that institutional quality and human capital have a positive and significant impact on economic growth of Pakistan both in the short as well as in long run. Furthermore, both variables when worked from their mathematical averages; have a positive impact on economic growth. It can be concluded that strong institutional quality and improvement in human capital are essential determinants that accelerate economic growth in developing economies, especially in the case of Pakistan. Human capital accumulation increases productivity. The strong institutional quality enhances economic growth through 
the implementation of law and order. As a result, the economy moves towards a higher economic growth trajectory. The results of the study support both alternative hypotheses of the research. This paper argues that there is a dire need to develop human capital and institutional quality impressively, which helps to boost the growth of Pakistan's economy. It is also recommended that the law and order situation must be improved so that the confidence and trust of investors is restored, and they contribute positively to the economic growth of Pakistan. 


\section{References}

Abbas, Q. (2000). The role of human capital in economic growth: A comparative study of Pakistan and India. The Pakistan Development Review, 39(4), 451469.

Abbas, Q. (2001). Endogenous growth and human capital: A comparative study of Pakistan and Sri Lank. The Pakistan Development Review, 40(4), 987-1007.

Abbas, Q. \& Foreman-Peck, J. (2007). Human capital and economic growth: Pakistan, 1960 2003. Cardiff Economics, Working Papers, 2007/22.

Acemoglu, D., Johnson, S. \& Robinson, J. (2004). Institutions as a fundamental cause of long run growth. National Bureau of Economic Research, 10481.

Acemoglu, D., Johnson, S. \& Robinson, J. A. (2005). Institutions as a fundamental cause of long-run growth. Handbook of Economic Growth, 1, 385-472.

Acemoglu, D., Gallego, F. A., \& Robinson, J. A. (2014). Institutions, human capital, and development. Annual Review of Economics, 6(1), 875-912.

Adams-Kane, J., \& Lim, J. J. (2016). Institutional quality mediates the effect of human capital on economic performance. Review of Development Economics, 20(2), 426-442.

Afridi, A. H. (2016). Human capital and economic growth of Pakistan. Business and Economic Review, 8(1), 77-86.

Ahmed, S. (2006). Explaining south Asia's development success: The role of good policies. World Bank Publications, Available at: https://doi.org/10.1596/978-0-8213-6599-1

Ali, S., Chaudhry, I.S. \& Farooq, F. (2012). Human capital formation and economic growth in Pakistan. Pakistan Journal of Social Sciences, 32(1), 229-240.

Angeles, L. (2010). Demographic transitions: Analyzing the effects of mortality on fertility. Journal of Population Economics, 23(1), 99-120.

Asghar, N., Awan, A., \& Rehman, H. (2012). Human capital and economic growth in Pakistan: A cointegration and causality analysis. International Journal of Economics and Finance, 4(4), 135-147.

Barro, R. J. (1990). Government spending in a simple model of endogenous growth. Journal of Political Economy, 98(5), 103-125.

Barro, R. J. (1991). Economic growth in a cross-section of countries. The Quarterly Journal of Economics, 106(2), 407-443. 
Barro, R. J. (1998). Human capital and growth in cross country regressions. Swedish Economic Policy Review, 6(2), 237-277.

Baum, M. A., \& Lake, D. A. (2003). The political economy of growth: Democracy and human capital. American Journal of Political Science, 47(2), 333-347.

Becker, G. S., Murphy, K. M. \& Tamura, R. (1990). Human capital fertility and economic growth. Journal of Political Economy, 98(5), 12-37.

Bhattacharjee, J. (2017). Do institutions affect economic growth? An empirical analysis of selected South Asian countries. Asian Journal of Comparative Politics, 2(3), 243-260.

Castelló, A., \& Doménech, R. (2002). Human capital inequality and economic growth: Some new evidence. The Economic Journal, 112(478), 187-200.

Dias, J. \& Tabaldi, E. (2012). Institutions, human capital, and economic growth: The institutional mechanism. Structural Change and Economic Dynamics, 23, 300-312.

Eicher, T. S. \& Leukert, A. (2009). Institutions and economic performance: Endogeneity and parameter heterogeneity. Journal of Money, Credit and Banking, 41(1), 197-219.

Faria, J. R. \& Carneiro, F. G. (2001). Does inflation affect growth in the long and short run? Journal of Applied Economics, 14(1), 89-105.

Glaeser, E. L., La Porta, R., Lopez-de-Silanes, F. \& Shleifer, A. (2004). Do institutions cause growth? Journal of Economic Growth, 9(3), 271-303.

Government of Pakistan. (2016). Pakistan economic survey 2015-16. Ministry of Finance, Islamabad.

Harbinson, F. \& Myers, C. A. (1964). Education and employment in the newly developing economies. Comparative Education Review, 8(1), 5-10.

Harbison, F. H., \& Myers, C. A. (1964). Education, manpower, and economic growth: Strategies of human resource development. Tata McGraw-Hill Education.

Khan, B. Z. \& Sokoloff, K. L. (2004). Institutions and democratic invention in $19^{\text {th }}$ century America: Evidence from 'great inventors' 1790-1930. The American Economic Review, 94(2), 395-401.

Khan, M. S. (2005). Human Capital and Economic Growth in Pakistan. The Pakistan Development Review, 44(4), 455-478. 
Khan, M. S. \& Senhadji, A. S. (2001). Threshold effect in the relationship between inflation and growth. Palgrave MacMillan Journal, 48(1), 1-21.

Knack, S. \& Keefer, P. (1995). Institutions and economic performance: Cross country tests using alternative institutional measures. Economics and Politics, 7(3), 207-227.

Knack, S. \& Keefer, P. (1997). Why don't poor countries catch up? A cross national test of an institutional explanation. Economic Inquiry, 35(3), 590-602.

Levchenko, A. A. (2007). Institutional quality and international trade. The Review of Economic Studies, 74(3), 791-819.

Lucas Jr, R. E. (1988). On the mechanics of economic development. Journal of Monetary Economics, 22(1), 3-42.

Mankiw, N. G., Romer, D. \& Weil, D. N. (1992). A contribution to the empirics of economic growth. The Quarterly Journal of Economics, 107(2), 407-437.

Musai, M. \& Mehrara, M. (2013). The relationship between economic growth and human capital in developing countries. International Journal of Social and Humanistic Sciences, 5(55), 55-62.

Nasir. J. (2018). Pakistan among the lowest ranked countries in human capital index: World bank. Available at: https://propakistani.pk/2018/10/15/pakistan-among-the-lowestrankedcountries- n-human-capital-index-world-bank/

Nawaz, S. (2015). Growth effects of institutions: A disaggregated analysis. Economic Modelling, 45, 118-126.

North, D. C. (1990). Institutions, institutional change, and economic performance. Cambridge University Press, New York.

North, D. C. (1991). Institutions. Journal of Economic Perspectives, 5(1), 97-112.

Pesaran, M. H., Shin, Y. \& Smith, R. J. (2001). Bounds testing approaches to the analysis of level relationships. Journal of Applied Econometrics, 16(3), 289-326.

Phillips, P. C. B. \& Ouliaris, S. (1990). Asymptotic properties of residuals-based tests for cointegration. Econometrica, 58(1), 165-193.

Rodrik, D. (1999). Where did all the growth go? External shocks, social conflict, and growth collapse. Journal of Economic Growth, 4(4), 385-412. 
Rodrik, D. (2003). In search of prosperity: Analytic narratives on economic growth. Princeton University Press, Princeton, New Jersey.

Rodrik, D., Subramanian, A. and Trebbia, F. (2004). Institutions rule: The primacy of institutions over geography and integration in economic development. Journal of Economic Growth, 9(2), 131-165.

Romer, P. M. (1989). Human capital and growth: Theory and evidence. In Carnegie Rochester Conference Series on Public Policy, 32, 251-286.

Romer, P. M. (1990). Endogenous technological change. Journal of Political Economy, 98(5), 71-102.

Schultz, T. P. (1993). Investments in the schooling and health of women and men: Quantities and returns. Journal of Human Resources, 28(4), 694-734.

Slesman, L., Baharumshah, A. Z. \& Ra'ees, W. (2015). Institutional infrastructure and economic growth in member countries of the Organization of Islamic Cooperation (OIC). Economic Modeling, 51, 214-226.

Sokoloff, K. L., \& Khan, B. Z. (1990). The democratization of invention during early industrialization: Evidence from the United States, 1790-1846. The Journal of Economic History, 50(2), 363-378.

Tamura, R. (1991). Income convergence in an endogenous growth model. Journal of Political Economy, 99(3), 522-540.

Tariq, N., Butt, A. R. \& Qasim, H. M. (2016). Relationship between institutions and economic growth: A cross country time series analysis. International Journal of Economics and Empirical Research, 4(7), 364-375.

Todaro, M. \& Smith, S. (2015). Case studies in economic development. George Washington University.

Valeriani, E. \& Peluso, S. (2011). The impact of institutional quality on economic growth and development: An empirical study. Journal of Knowledge Management, Economics, and Information Technology, 1(6), 1-25.

Yilmazer, M. \& Cinar, S. (2015). Human capabilities and economic growth: A comparative human capability index. International Journal of Economics and Financial Issues, 5(4), 843-853.

Zhou, Y. (2018). Human capital, institutional quality, and industrial upgrading: Global insights from industrial data. Economic Change and Restructuring, 51(1), 1-27. 
An Empirical Relationship Between Human Capital, Institutional Quality, and Economic Growth in Pakistan

\section{Appendix 1}
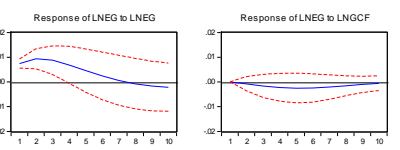

Impulse Response Function
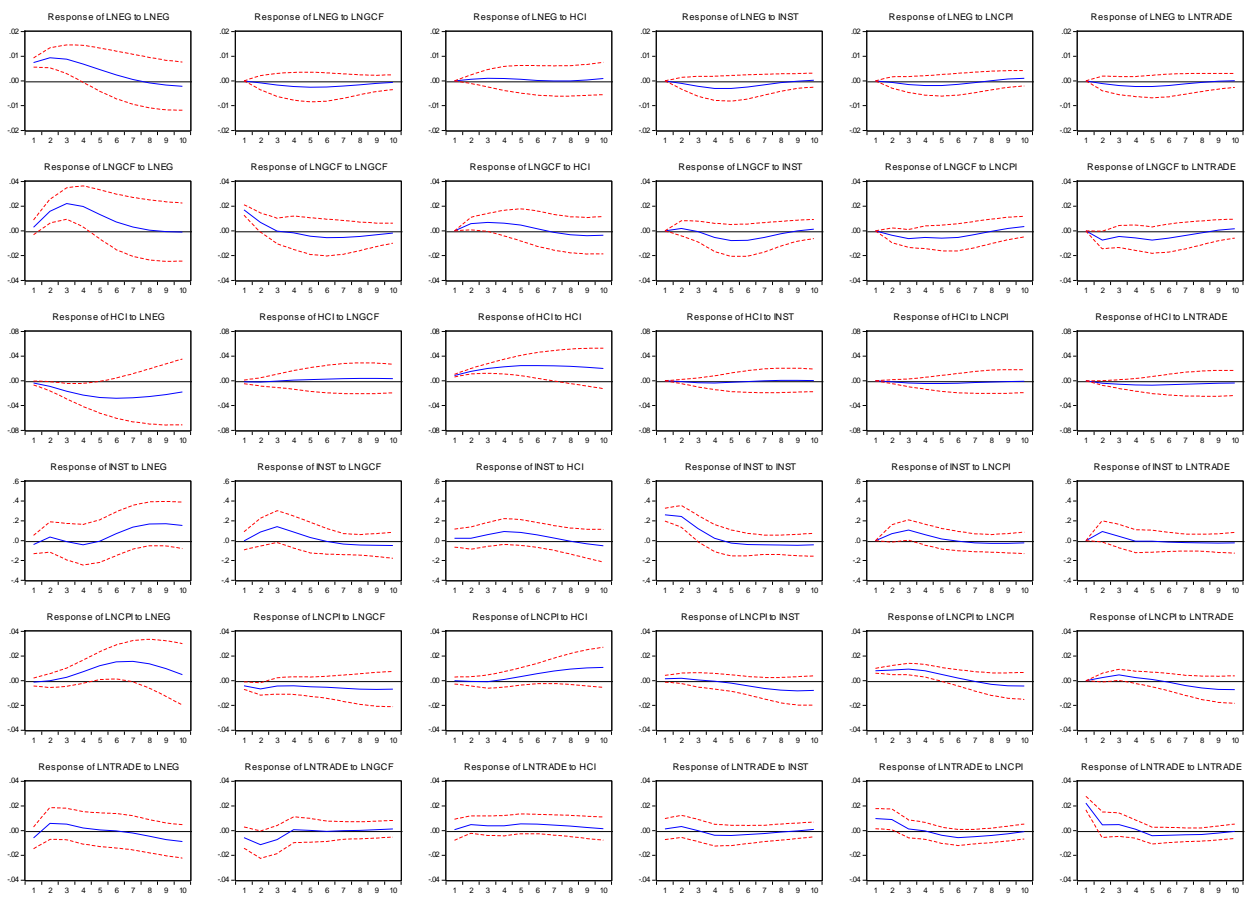


\section{Appendix 2}

Variance Decomposition Analysis

\begin{tabular}{|c|c|c|c|c|c|c|c|}
\hline \multirow[b]{2}{*}{ Period } & \multirow[b]{2}{*}{ S.E. } & \multirow[b]{2}{*}{ LNEG } & \multicolumn{4}{|c|}{ Variance Decomposition of LNEG: } & \multirow[b]{2}{*}{ LNTRADE } \\
\hline & & & LNGCF & LNHCI & LNINST & LNCPI & \\
\hline 1 & 0.007434 & 100.0000 & 0.000000 & 0.000000 & 0.000000 & 0.000000 & 0.000000 \\
\hline 2 & 0.012101 & 97.64119 & 0.377448 & 0.321588 & 0.642159 & 0.271425 & 0.746189 \\
\hline 3 & 0.015427 & 92.49642 & 1.412309 & 0.678599 & 2.427093 & 1.049579 & 1.935998 \\
\hline 4 & 0.017564 & 86.58610 & 2.677220 & 0.837727 & 4.818140 & 1.935517 & 3.145298 \\
\hline 5 & 0.018807 & 81.36842 & 4.105562 & 0.847119 & 6.819474 & 2.636332 & 4.223093 \\
\hline 6 & 0.019417 & 77.87840 & 5.475398 & 0.808007 & 7.969509 & 2.986586 & 4.882099 \\
\hline 7 & 0.019649 & 76.14287 & 6.491464 & 0.789561 & 8.399785 & 3.024945 & 5.151373 \\
\hline 8 & 0.019748 & 75.53421 & 7.055438 & 0.781711 & 8.436004 & 2.999509 & 5.193133 \\
\hline 9 & 0.019864 & 75.37700 & 7.234668 & 0.804730 & 8.338517 & 3.108068 & 5.137013 \\
\hline 10 & 0.020044 & 75.17502 & 7.182490 & 1.034223 & 8.208927 & 3.350889 & 5.048451 \\
\hline
\end{tabular}

\begin{tabular}{|c|c|c|c|c|c|c|c|}
\hline \multicolumn{8}{|c|}{ Variance Decomposition of LNGCF: } \\
\hline Period & S.E. & LNEG & LNGCF & LNHCI & LNINST & LNCPI & LNTRADE \\
\hline 1 & 0.017202 & 2.810583 & 97.18942 & 0.000000 & 0.000000 & 0.000000 & 0.000000 \\
\hline 2 & 0.026468 & 37.29001 & 47.64271 & 4.802269 & 0.581345 & 1.844453 & 7.839218 \\
\hline 3 & 0.035995 & 57.85813 & 25.76454 & 6.202969 & 0.349524 & 3.959272 & 5.865559 \\
\hline 4 & 0.042579 & 62.74997 & 18.56081 & 6.555652 & 1.838092 & 4.385469 & 5.910002 \\
\hline 5 & 0.046732 & 60.25990 & 16.27983 & 6.467706 & 4.306573 & 5.198759 & 7.487231 \\
\hline 6 & 0.048902 & 57.25417 & 16.15989 & 6.033050 & 6.321366 & 5.916891 & 8.314636 \\
\hline 7 & 0.049818 & 55.56095 & 16.68502 & 5.869166 & 7.222177 & 6.066890 & 8.595798 \\
\hline 8 & 0.050206 & 54.72213 & 17.23459 & 6.172494 & 7.323752 & 5.982432 & 8.564595 \\
\hline 9 & 0.050505 & 54.09183 & 17.42808 & 6.720014 & 7.237686 & 6.047577 & 8.474821 \\
\hline 10 & 0.050845 & 53.41092 & 17.32792 & 7.115654 & 7.222903 & 6.438233 & 8.484372 \\
\hline
\end{tabular}

\begin{tabular}{|c|c|c|c|c|c|c|c|}
\hline \multicolumn{8}{|c|}{ Variance Decomposition of LNHCI: } \\
\hline Period & S.E. & LNEG & LNGCF & LNHCI & LNINST & LNCPI & LNTRADE \\
\hline 1 & 0.009412 & 14.46108 & 3.255081 & 82.28384 & 0.000000 & 0.000000 & 0.000000 \\
\hline 2 & 0.020758 & 22.04533 & 1.490748 & 72.21270 & 0.404104 & 0.611768 & 3.235343 \\
\hline 3 & 0.034031 & 32.44483 & 0.560302 & 61.13980 & 0.928493 & 1.251509 & 3.675060 \\
\hline 4 & 0.047871 & 39.72842 & 0.358749 & 53.72813 & 0.987803 & 1.396476 & 3.800423 \\
\hline 5 & 0.060722 & 44.17300 & 0.325185 & 49.62446 & 0.787082 & 1.391709 & 3.698569 \\
\hline 6 & 0.071777 & 46.89903 & 0.372298 & 47.44928 & 0.590236 & 1.273394 & 3.415768 \\
\hline 7 & 0.080943 & 48.43126 & 0.473474 & 46.36828 & 0.464142 & 1.115353 & 3.147485 \\
\hline 8 & 0.088259 & 49.09287 & 0.590721 & 46.00191 & 0.395742 & 0.980251 & 2.938500 \\
\hline 9 & 0.093789 & 49.10702 & 0.699697 & 46.15889 & 0.357914 & 0.882984 & 2.793499 \\
\hline 10 & 0.097686 & 48.65586 & 0.780021 & 46.69640 & 0.333392 & 0.820448 & 2.713876 \\
\hline
\end{tabular}


An Empirical Relationship Between Human Capital,

Institutional Quality, and Economic Growth in Pakistan

\begin{tabular}{|c|c|c|c|c|c|c|c|}
\hline \multicolumn{8}{|c|}{ Variance Decomposition of LNINST: } \\
\hline Period & S.E. & LNEG & LNGCF & LNHCI & LNINST & LNCPI & LNTRADE \\
\hline 1 & 0.266477 & 2.226900 & 0.007665 & 0.836785 & 96.92865 & 0.000000 & 0.000000 \\
\hline 2 & 0.392206 & 1.891744 & 4.989817 & 0.747297 & 83.45129 & 3.334655 & 5.585194 \\
\hline 3 & 0.454086 & 1.469266 & 13.54135 & 2.426636 & 69.34863 & 8.076172 & 5.137949 \\
\hline 4 & 0.477681 & 2.094698 & 15.52929 & 5.906755 & 62.93587 & 8.874684 & 4.658697 \\
\hline 5 & 0.486819 & 2.026571 & 15.36084 & 8.572328 & 60.86590 & 8.672536 & 4.501821 \\
\hline 6 & 0.497070 & 3.911156 & 14.76266 & 9.565554 & 59.03585 & 8.328996 & 4.395779 \\
\hline 7 & 0.519663 & 10.37581 & 13.96563 & 9.018900 & 54.66468 & 7.794790 & 4.180190 \\
\hline 8 & 0.551204 & 18.62714 & 13.04780 & 8.023452 & 49.22769 & 7.190601 & 3.883315 \\
\hline 9 & 0.582878 & 25.28661 & 12.30179 & 7.464000 & 44.63290 & 6.657886 & 3.656818 \\
\hline 10 & 0.609327 & 29.48826 & 11.87934 & 7.581246 & 41.33321 & 6.237298 & 3.480650 \\
\hline
\end{tabular}

\begin{tabular}{cccccccc}
\hline \multirow{2}{*}{ Period } & \multirow{2}{*}{ S.E. } & LNEG & Lariance Decomposition of LNCPI: & & \\
& & & & & & \\
& & & & & & \\
& & & & & & \\
2 & 0.009092 & 1.459291 & 19.47801 & 0.004882 & 2.812559 & 76.24526 & 0.000000 \\
3 & 0.014508 & 0.573338 & 28.88660 & 0.157092 & 2.778946 & 64.66122 & 2.942807 \\
4 & 0.018630 & 2.404550 & 22.85807 & 0.309951 & 1.803048 & 64.65598 & 7.968409 \\
5 & 0.022114 & 12.41168 & 19.51810 & 0.425534 & 1.325323 & 59.28647 & 7.032900 \\
6 & 0.026451 & 29.39002 & 17.10069 & 1.889826 & 1.485915 & 45.10317 & 5.030383 \\
7 & 0.037650 & 43.00890 & 14.64388 & 4.472906 & 2.676310 & 31.59083 & 3.607165 \\
8 & 0.042875 & 48.32835 & 13.16537 & 7.582550 & 4.607559 & 22.68553 & 3.630636 \\
9 & 0.047172 & 43.39151 & 12.64877 & 10.66953 & 6.760372 & 17.89522 & 4.634589 \\
10 & 0.050469 & 38.96268 & 12.66957 & 13.61760 & 8.679867 & 15.53028 & 6.012481 \\
& & & 12.90813 & 16.47101 & 10.02823 & 14.28090 & 7.349056
\end{tabular}

\begin{tabular}{|c|c|c|c|c|c|c|c|}
\hline \multicolumn{8}{|c|}{ Variance Decomposition of LNTRADE: } \\
\hline Period & S.E. & LNEG & LNGCF & LNHCI & LNINST & LNCPI & LNTRADE \\
\hline 1 & 0.025740 & 5.272125 & 4.937374 & 0.077584 & 0.249542 & 14.36056 & 75.10282 \\
\hline 2 & 0.031095 & 7.145908 & 16.85526 & 2.533813 & 1.380949 & 18.31940 & 53.76467 \\
\hline 3 & 0.032995 & 8.965462 & 19.82887 & 3.656979 & 1.226582 & 16.44998 & 49.87212 \\
\hline 4 & 0.033537 & 9.099683 & 19.24592 & 4.915670 & 2.417362 & 15.92641 & 48.39495 \\
\hline 5 & 0.034671 & 8.550605 & 18.01001 & 7.099448 & 3.568311 & 16.11027 & 46.66136 \\
\hline 6 & 0.035860 & 7.996448 & 16.86292 & 8.757626 & 4.141196 & 17.58667 & 44.65514 \\
\hline 7 & 0.036749 & 7.885285 & 16.05719 & 9.829331 & 4.348891 & 18.51812 & 43.36119 \\
\hline 8 & 0.037570 & 9.011817 & 15.36628 & 10.37887 & 4.271869 & 18.77331 & 42.19785 \\
\hline 9 & 0.038475 & 12.07882 & 14.69092 & 10.36088 & 4.075330 & 18.30987 & 40.48418 \\
\hline 10 & 0.039560 & 16.40198 & 14.03166 & 9.971256 & 3.910644 & 17.36127 & 38.32319 \\
\hline
\end{tabular}

Cholesky Ordering: LNEG LNGCF LNHCI LNINST LNCPI LNTRADE 